\title{
National and Racial Images of the Sexual 'Other' in the German-Speaking Countries (1950s-1970s)
}

\author{
Franz X. Eder ${ }^{1}$
}

Published online: 7 March 2016

(c) The Author(s) 2016. This article is published with open access at Springerlink.com

\begin{abstract}
During the 'long' sexual revolution — or better, sexual liberalization and sexualization-there was a broad discussion about the national origins of sexual images as well as modes of behaviour in the German-speaking countries. Writers, journalists and scientists argued that especially American, French and Swedish images could have an important impact on the changes of their own 'sexual climate'. They also discussed about the sexuality of 'black people' and the differences between their habits and the national sex culture. This article shows and compares the different national sex images of women and their reception in the 'German' and 'Austrian' popular sex discourse. Using examples of weekend and youth magazines, popular advice books and films, it asks why these national images were discussed and what their social, cultural and political context was.
\end{abstract}

Keywords Gender rolls - Sexual revolution - Sexual images · Media discourse

In recent years, the history of the sexual revolution in German-speaking countries became a new topic of historical research and research in the social sciences and cultural studies (see the literature and references in Bänziger and Stegmann 2010;

Franz X. Eder

franz.eder@univie.ac.at

1 Department of Economic and Social History, University of Vienna, Universitätsring 1, 1010 Vienna, Austria 
Eder 2014, 2015; Bänziger et al. 2015). One of the main questions of this debate was and is whether the sexual revolution took place in the late 1960s and in the 1970 s or whether this short phase has to be seen as part of a long-term process, which already started in the post-war years. According to my point of view, the initial manifestations of a longer process could already be recognized in the early 1950s (For a critical discussion of the concept of the 'sexual revolution' and it periodisation in the twentieth century, cf. Hekma and Giami 2014, Eder 2014. For longer perspective also cf. Cook 2004, Dabhoiwala 2012). As we will see, the erotization of the 1950s and 1960s happened in a diffuse way and as a 'soft' or gradual sexualization. One cannot deny that in the mid-1960s the debates became more intensive and attracted a wider public attention. However, this was foremost an outdated discourse catching up with the commodification, normalization and politicization of sexual culture which had already been occurring for quite some time.

In this article I will focus on a certain aspect of the 'long' sexual revolution in West Germany and Austria: The sexual images ${ }^{1}$ of the female 'other' and their function in constructing a national sexual identity in the phase from the 1950s to the late 1960s. Speaking about the sexual life of the 'other' had a long tradition in European history and even in the history of sexuality. In its 'orientalistic' and 'exotistic' version it produced sexual fantasies about the South Sea and the Indian as well as Arabian culture during the eighteenth and nineteenth centuries promising 'untiring sensuality, unlimited desire, [and] deep generative energies' (Said 1985, p. 188). ${ }^{2}$ In West Germany and Austria sexual images of the 'other' also were discussed and spread in the 1950s and 1960s (Eder 2007, 2014). During these years, writers, journalists and scientists were fascinated by US-American, French, Swedish and black sex images primarily of females and debated about the differences to their own sexual images as well as about their impact on the national sex culture. For this article I will focus on 'othering' images from weekend and youth magazines, advice books and movies and their social, cultural and political context. My discourse analysis $^{3}$ will ask about the tasks of these images of the 'other' and their function for the sex discourse in German-speaking countries. ${ }^{4}$

If legislators and religious leaders had had their way, an atmosphere of silence and continence would have reigned in Austrian and West German bedrooms in the 1950s and 1960s. Reconstruction and the 'economic miracle'-the fast economic

\footnotetext{
${ }^{1}$ For my perspective on images and their analysis in the historical context, see Eder and Kühschelm 2014; an overview on the theory and practice of image/picture studies is given by Manghani 2013.

2 The literature on othering and exotism in the history of the body and sexuality is extensive. See, e.g. the references in Varisco 2007; Marklund and Glover 2009; Mar Castro Varela and Dhawa 2005; Reuter 2002; Gernig 2001.

${ }^{3}$ For the methods of historical discourse analysis, cf. Eder 2006.

4 Only a few studies have addressed this topic for the German-speaking countries yet most of them focusing certain media products. cf. Schröder 1996; Eder 2007, 2014; Mayer 2014.
} 
rise after the war-were founded on the stable nuclear family, with a clear division of the sexes and a sexual morality based on marriage (Kral 2004). However, behind the general morals the first indications of sexualization could be seen (Eder 2009, p. 211ff.; Steinbacher 2011, p. 21ff.). This is reflected in the interest in literature on sex education, contraceptives and the demand for mail-order erotica, e.g. sold by the Beate Uhse Company (which by the early 1960s reached half of the West German households) (Heineman 2006, p. 847, 853; 2011a). In doing so, writers and photographers used different strategies for the representation of the eroticized and sexualized female-males played a minor role as sexual objects in this discourse. One of them was to question the status of females in other nations and cultures and to compare them with their position in West Germany and Austria.

In doing so, most frequently US-American females came into the focus of attention. Two types can be found very often: The erotic pinup girl and the Hollywood starlet. A typical representative of the latter can be seen on the pages of the popular Viennese magazine Wiener Magazin from 1959.

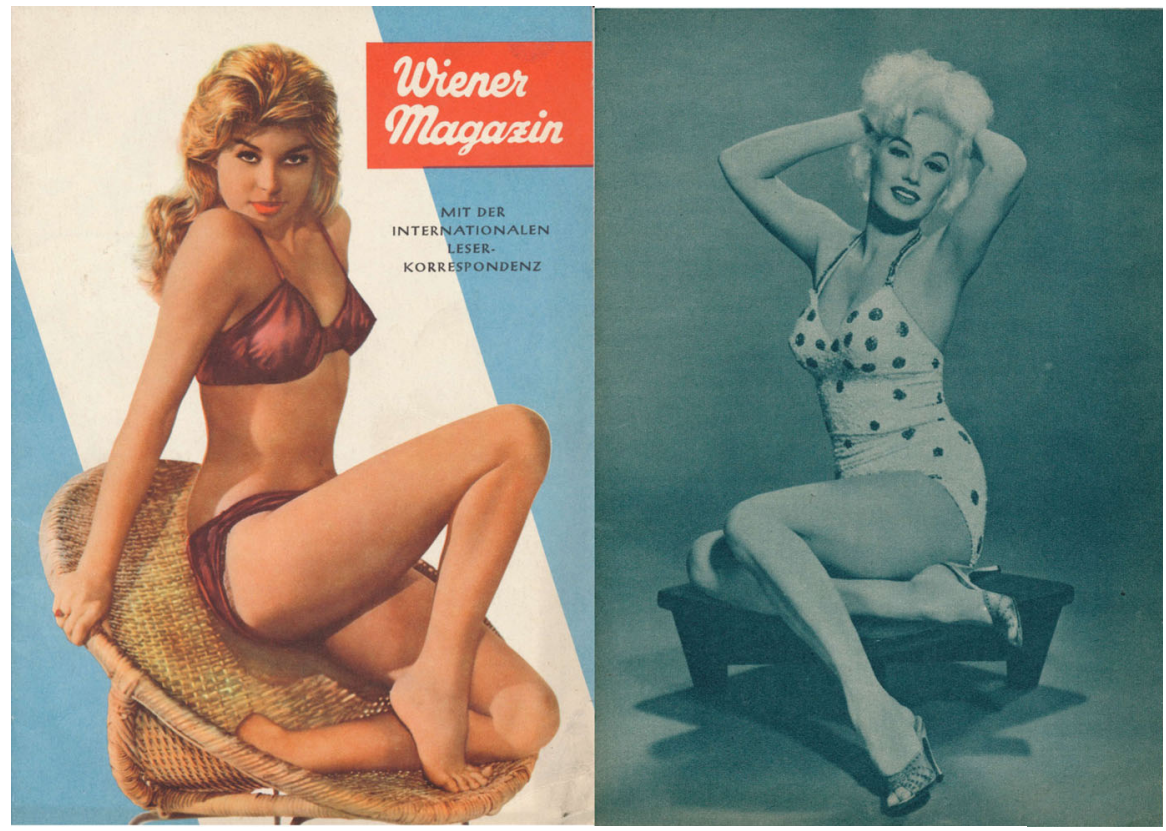

Wiener Magazin 1959, No 9 (front page and p. 5)

In the surrounding texts these females were primarily labelled as rather naive girls, who used their exciting bodies for a career as film actress or to marry a rich man. But the authors argued in a contradictory way: On the one hand these females seemed to be highly erotic and 'hot' candidates for a love affair and even for 
marriage. On the other hand the writers were more or less sceptical: Would these women evolve into faithful and trusty spouses? Would they be able to canalize their sex appeal in the marital bedroom?

Already in 1951, the Germans and Austrians could study the 'truth about the pinup girls' in another illustrated magazine called Cocktail: 'The normal and average person has a totally inapplicable notion of the mental primitivism of the beauties of this continent [Northern America]. Especially the "super pinup girls", the photo models and movie stars are very problematic wives and it is no accident that Hollywood marriages are divorced three times more than all other Americans (...), because of their strenuous job and the often intoxicating success, most of them have become vain and hard. Love is a sideline for them and even marriage is not taken seriously. These women pay homage to a unlimited individualism and have totally forgotten to meet their husband half way' (Cocktail 1951, No. 11, p. 25). According to this journalist, these females were desired because of their sex appeal, but they also scared the Austrian men because they did not fit into the traditional roles as spouses, housewives and mothers.

The 'Coca-Colonization' or 'Americanization' of media is one of the reasons why we can find such images of American women in German and Austrian magazines since the late 1940s and the 1950s (Wagnleitner 1994; Koch and Tallafuss 2007). Thereby sexuality became a 'hot' political issue. In discussing sex and society, one also could consider the cultural traditions of the Nazi era. For religious groups and the political parties, the negative distinction from the NSregime and its ideology was obvious. As demonstrated by the 'filth-and-trash' debate around 1950, clergy and politicians wanted to detach from the permissive sexual ideology of the NS and its sexual-friendly, pro-natalistic measures on the one hand and from the lax sexual morality of the post-war period which had tolerated pre- and extra-marital sexual contacts, abortion, contraception and prostitution on the other hand (Herzog 2005; Eder 2007; Heineman 2011b). 'Normalization' was the buzzword used to characterize the gender relations in the 1950s and which promised a healing of the 'wounds of history': 'Normality would "undo" some of the consequences of the war and make people forget some of their most painful memories. It would bridge the rift between men and women after the devastating experience of war and after the struggle for survival in the postwar period' (Schissler 2001, p. 361). In this situation the sexualized American type of woman would hamper the search for 'normal' love and marriage. Due to increasing female employment, wives and mothers would mutate to more autonomous persons, who in the end would even emancipate themselves in sexual matters- these were the fears of the male authors, who had the say in popular magazines. The few female authors were not that sceptical towards these media images of the American woman, because they also promised a general reduction of male privileges (Steinbacher 2011, p. 182ff.). 
For instance, an article published in the German women's magazine and glossy Constanze notes in 1951: 'The National Socialists' 'healthy sensuality' was followed by America's influence. Americans' expression of sexual privation really is not our business. Not long ago, one would have suggested that they deal with their desires on their own. Today, they are in our midst with all their glamour girls, their award-winning buttocks, their young men, who claim to be experts and to use manometers to measure the excitement factor of competing female breasts. Today, they are being copied and even trumped. They have helped us generally to enforce the sportive approach to love which had already started to take shape under Hitler (...). The atmosphere surrounding us grows more and more free of the refined currents of female attraction and erotic courtship. Make the brassieres even smaller, design the slips to be even tighter, fill your horizon with the spikes of the female torso, put nakedness on every butter wrapping, be sure no magazine cover goes without voluptuous thighs - none of this is going to help you; the world will only grow even more devoid of love. Erotic excitement [will] slacken and give way to sexual privation seeking hasty satisfaction' (Sieburg 1951, p. 7). Nevertheless in 1952, the female readership of Constanze was lead to believe that the 'young American woman' could serve as a model for sexual equality in West Germany because she 'wants to be desired, under the condition that she may share the desire' (Hoffmann 2000, p. 63).

Magazines like Cocktail and Constanze were leading media for the spread of the erotic and sexual imagery of the 'foreign' woman. This was also the result of the first large-scale survey on sexual behaviour and opinions by the German Institute of Demography (in 1949) (Friedeburg 1953, p. 88). The sexualization of the media, especially the easy access to erotic images, was hotly discussed in those years. As far as the law was concerned, old regulations about 'indecent behaviour' were still valid until 1950, incriminating all visual representations and indecent public activities. Due to the 'dirt and trash' law (enacted in Austria 1950, in Germany 1953), erotic illustrations were heavily restricted (Blaschitz 2014). With this legal standard, conservative parties and the clergy had created a highly flexible tool to censor public images and language. Unexpectedly, however, this obsession with repression and regulation also resulted in promoting sexuality as a prominent topic of public discussion-'sex' became a 'hot' and number one topic of the 1950s and 1960s.

One strategy to speak and write about sexuality in public was to discuss the Kinsey reports and to compare their statistical outcomes about the Americans with the sexual habits and opinions in Germany and Austria (Steinbacher 2011, p. 137ff and 166 ff.). Leo Dembicki und Willy Feyerabend, two physicians, for instance wrote a book on 'The female sexuality. An examination of Kinsey' (in 1954) in which they compared the American and German, respectively, Austrian women. Because of the material prosperity and advanced emancipation of women, in their eyes American marriages got a 'temporary, playful and sexualized character' (Dembicki and Feyerabend 1954, p. 198). With the mirror of the sexualized 
American woman, they discussed whether the consumer society would change the German and Austrian females, too. They assumed that 'sexual techniques will be established in all higher social classes and education groups and they will replace all moments of personal love relation and erotic' (Dembicki and Feyerabend 1954, p. 259f.). According to them Americans experience a problematic gap between sexual morals and sexual practices. This could be observed in all forms of 'half sexualized' behaviour-e.g. in petting, a practice which was more common in the USA than in Europe and which they saw as a minor form of sex (because there is no penetration). Dagmar Herzog has shown that in the reception of the Kinsey reports 'numerous continental European commentators saw an [American] wasteland that lacked any genuine eroticism' (Herzog 2006, p. 40).

For Eva Menzel and Günter Kraft, the authors of an advice book called 'The two sexes. Love and marriage in human relations' (Menzel and Kraft 1961), the popularization of the American sex reports was the reason why 'the sexual adventuresomeness and erotic success became an oversized idea for both sexes, which dominated all other necessaries and tasks of life'. Particularly women 'who do neither find fulfilment and justification in occupational work nor in familial duties' will concentrate all their efforts on the 'sexy' competition between themand on the question: 'Are they [the other women] erotically superior to me, do they have the same chances as I or is the victory certainly mine?' (Menzel and Kraft 1961, p. 26).

In the 1950s the 'sexy' topic could be found on the front pages and in the body of widespread magazines and glossies (Eder 2009, p. 217ff.). ${ }^{5}$ Reports on American youth culture, e.g. on the Rock and Rollers-and especially Elvis Presleypresented the new, 'sexy' generation. In Austria and Germany, sexual connotations emanating from Elvis's twitching pelvis embodied a downfall of civilization. Consequently, people thought of the degenerate and lascivious 'Negro' music, denunciations which bore a striking resemblance to NS propaganda. Some German newspapers suspected 'that Presley must have black blood in his ancestry to be able to move and sing in this extraordinary fashion' (Poiger 1996, p. 589).

\footnotetext{
5 Illustrated magazines like BRAVO, Constanze, Neue Illustrierte, Praline, Revue, Wiener Magazin and Wochenend presented a variety of rubrics: travel reports, cooking recipes, society news, movie reviews, reports on stars and starlets, fashion shoots, crossword puzzles, serial novels, broadcasting programs, a lot of advertising, etc. They were published once a week or in a two weekly interval, some of them even once a month and addressed a broad buyership. Some of these media were reshaped during the 1950s and 1960s - e.g. Praline, which between 1954 and 1958 was first published as a travelling magazine with serial novels, then as an illustrated journal with a focus on fashion, in the middle of the 1960s it became a women's magazine and since the late 1960s it more and more changed into a sex magazine. On the peak in the 1970s, about one million copies were sold. (Vogel 1998, p.107) Like all other magazines in this sample, the amount of pictures increased during the decades and black-and-white photos were replaced by coloured. Most of the glossies were produced by West German presses and were sold in Austria with some country-specific columns and articles.
} 


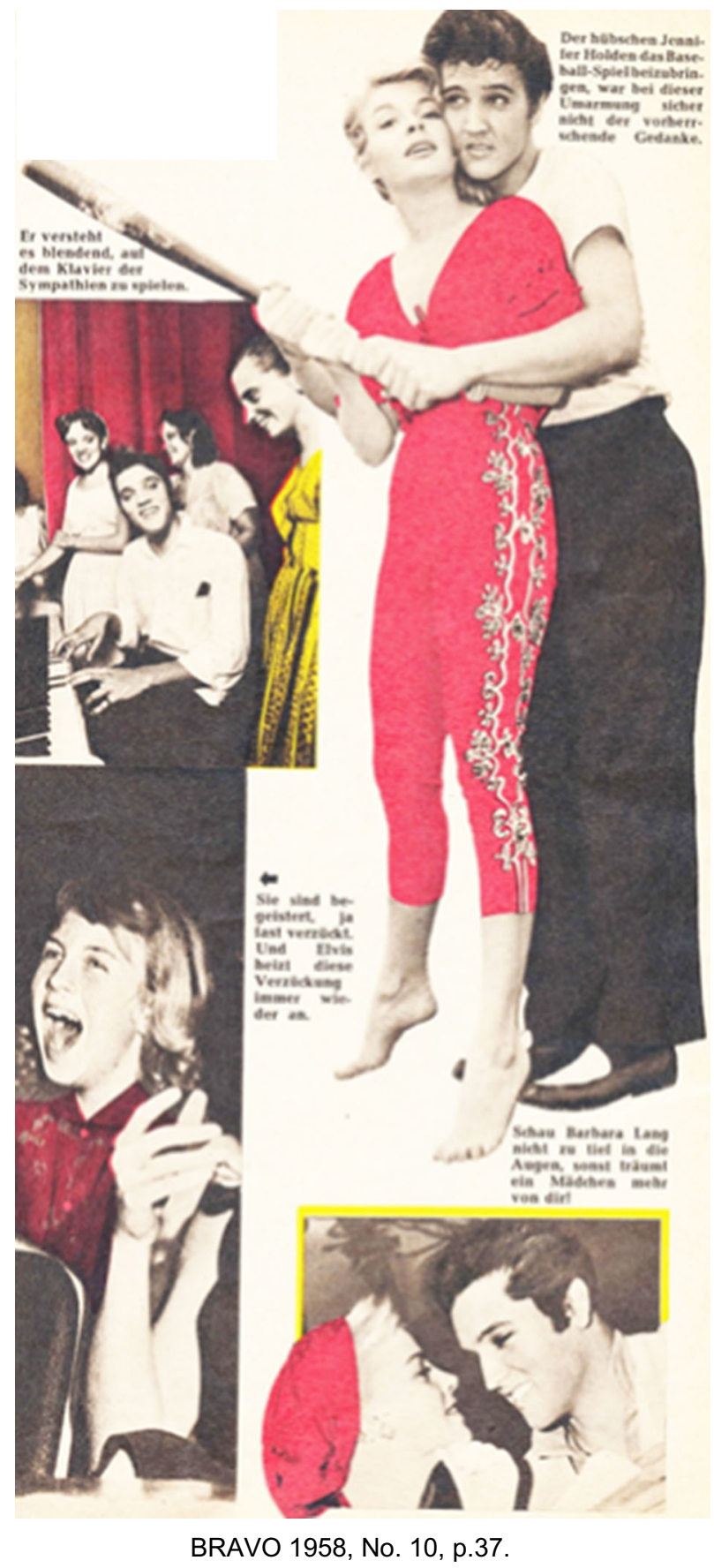


In an article of the famous BRAVO magazine from 1958, the readers were informed that Elvis had seduced a girl visiting one of his concerts and spent a night with her. The pictures showed the hysteric reactions of his female fans whichaccording to the author-were stimulated by Elvis' pelvis and his phallic guitar. Wild dancing styles were hardly compatible with the image of renewed Christian womanhood, which was propagated by the political parties and the church and centred on marriage and the family. Neither did the male identification image- the 'hooligan' or 'rebel' with his provocative attitudes-fit into the disciplinary male 'reconstruction mentality' of the 1950 s (Fichna 2004, p. 169). It was only a small step from Elivis' stimulating pelvis and his 'Negro' music to the image of the foreign and savage sexual mores and attitudes of the black and coloured people. Their sexual image was placed within 'nature' and therefore on a lower and primitive step of civilization (Mayer 2014, p. 52;60). ${ }^{6}$

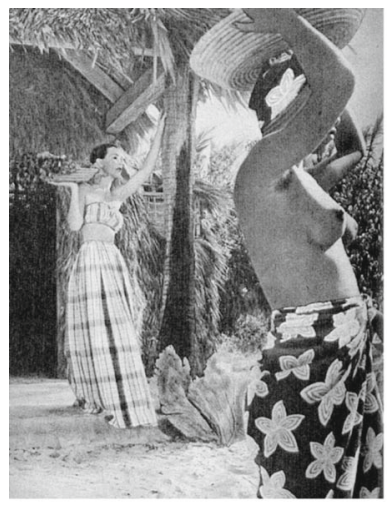

Praline 1955, No. 7, p.136
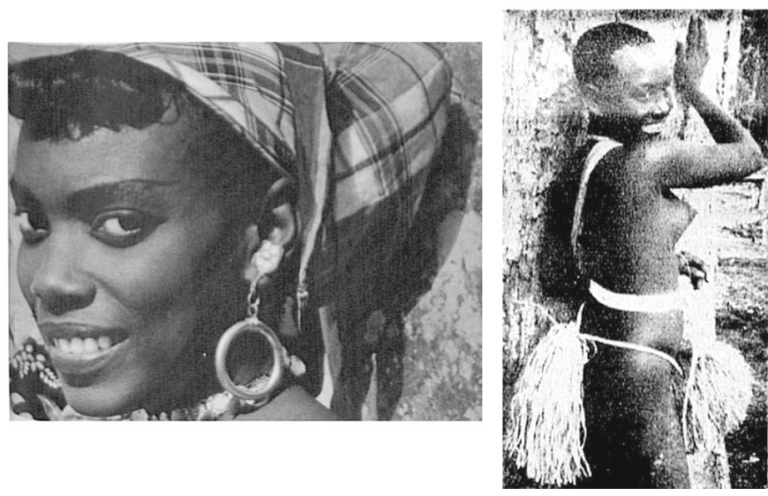

Praline 1955, No. 3, p.123 - Wochenend 1954, No. 33, p.11.

These three images of black and coloured women can be found in the German illustrated magazines Praline and Wochenend in the mid-fifties. The story on the two women from 'the Tropics' on the left side told the readers that the white woman in the background is dreaming to be a coloured native and to be seduced by 'a big wild Sahib' during an alluring night in the jungle. (Praline 1955, No. 7, p. 136) According to the subtitle, the sexual desire of the black woman in the middle was written in her face: 'Black eyes with their fascinating glance are a good index of a strong sex drive, says the scientist' (Praline 1955, No. 3, p. 123). The picture on the right showed a female 'Negrit' from the Andaman Islands. The legend below the picture explained: 'The single marriage is also known at the Andaman Islands. The girls are free until they are married. Spouses which don't want to live together anymore can divorce without any tragedy. They even don't know jealousy' (Wochenend 1954, No. 33, p. 11).

\footnotetext{
6 This atavistic label as well as Nazi racial ideology can also be found in the discourse about the black GIs. cf. Bauer 2002, p. 233f.; Brauerhoch 2006.
} 
In 1954 the Praline printed photographs of a dark and a white-coloured woman (one coming from New Zealand, the other from the USA) as a dichotomy of 'nature and civilization': 'The little New Zealander enchants with her animal naturalness, while the American operates with means and dodges of cosmetics, with fashion and charm' (Praline 1954, No. 12, p. 6f.). Such pictures showed the dark 'animal' woman close to nature and in an archaic context, which shaped her as primitive, exotic, determined by nature and classified by ethnicism and racism-all strategies of a discourse, which signified the self-representation of the white and Western woman as positive, the images of the other as negative (Wodak and Reisigl 2001, pp. 48ff; Mayer 2014, p. 48f). Who was enthralled by such 'wild beauties' had to reckon on their emotional instability, which was addressed in 1957 in an article titled 'Journeys to Paradise' in the Neue Illustrierte: White men, who found a playmate in the South Sea, should not hope for a longer relationship with her, because their 'girlfriend will not be constant. She will choose you, but you will not know why and she will leave you without knowing the reasons'. According to the author Leopold Fiedler, dark-skinned females will prevail over their white rivals in the battle for the favour of the white man. But the tie will be primarily a sexual one, because no real (marital) relation can emerge: 'Perhaps Europeans cannot experience the natural fortune, but in exchange we receive personal love' (Neue Illustrierte 1957, No. 2, p. 9).

In 1960 the Wiener Magazin associated the deficient love abilities of African 'Negroes' (Neger) with the economic foundation of matrimony, the easy way to get divorced and the encroachment of the Western consumer society: Divorce 'is relatively cheap for the Waganda negroes in central Africa. Even if they now have to pay the triple number of cows for a girl, they can quickly exchange her-if they do not like her anymore or she has made her unwanted-for an old bicycle or a radio (...)' (Wiener Magazin 1960, No. 7, p. 47). In a popular travel report titled 'The African Woman', which was published in the series 'Women of Foreign Nations (Völker)', the author provided another justification for the sexual attraction and the lacking love abilities of the Negress: 'Beyond the pleasures of sex life, the natives hardly know any other amusements and therefore the sex life is in the centre. It is much more intensive than the sex life of the Europeans, and above all the females take the initiative (...). The Negress only knows the sexual desire, she has a libidinous life, which also can be acknowledged by her unique motherly love' (Muthesius 1959, p. 100f.).

The images and fantasies of a 'savage' sexual life were ambivalent, too: On the one hand the male authors were fascinated by the promises of 'wild' and unsuppressed sexual adventures and experiences, which did not fit to the conservative Christian morals of their home countries. On the other hand they were scared of the archaic sexual power of these women, which could destroy the family and even the state order. In doing so, they reproduced the nineteenth-century myth and stereotype of the black woman, Julia S. Jordan-Zachery has called 'Jezebel' (named after the Biblical wife of King Ahab): Because of her 'race' this type of black female is thought to be sexually aggressive without any control and any resistance against her natural sexual desire, a seducer unable to rise civilized and rational citizens (Jordan-Zachery 2009, p. 39f.). 
The discrepancy between fantasies of a 'natural' sexual paradise and the reality of the post-war society ${ }^{7}$ can also been found in an article written by a Viennese reporter about a 'Wu-Du-Dancer' called Zita Baker whom he saw in a City night club in 1950.
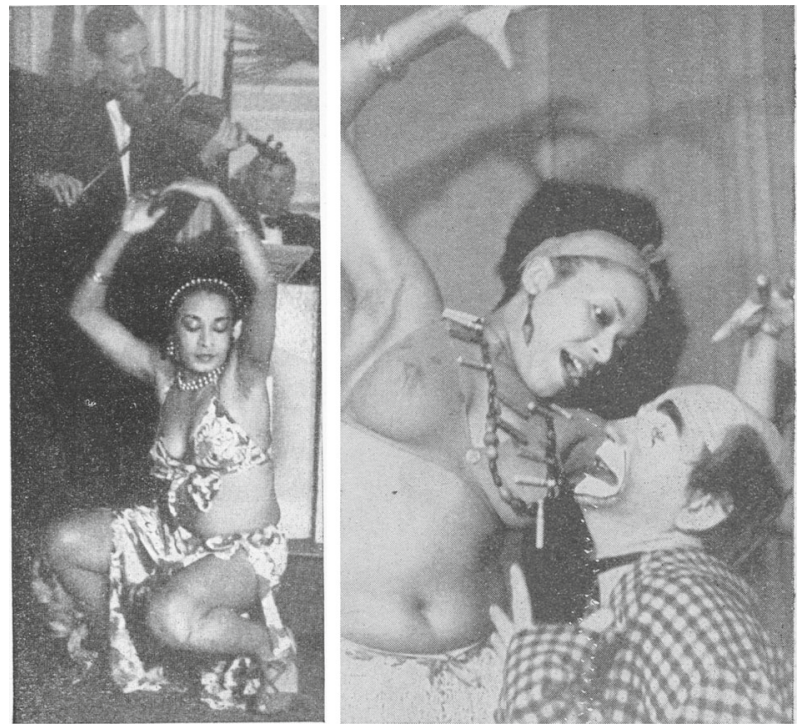

Cocktail 1950, No. 4, p.8f.

For him Baker performed 'a temple dance and an evocation of the beasts of the nightly jungle. It tells stories about the untamed sensuality of the human being, for which erotic is a sacral act'. In his interview with the dancer, the reporter was confronted with his own fantasies and prejudices: Baker told him that she wasn't a 'full Negro', not even coming from the jungle but a 'little Creole born in a middle class household in a town in French Guiana' - and she was named after the wife of the last Emperor of the Habsburg monarchy Zita (Cocktail 1950, No. 4, p. 8).

In the authors' world of ideas the wild and expressive sexual drives of the Negroes could be infectious for the whites and especially for the white woman. On the following photos from the Neuen Illustrierte (1962), one could see the sexual outgrowths even in the body language. On the left side one could gaze at 'Bantu mine workers', who had replaced their working clothes with ritual dresses and showed ecstatic dances. On the right side a German woman has been infected by the wild goings-on - commentated by the author as follows: 'The Bantus stop short when the noticed the white woman in their rows. When she joined the Bantu dances with a twitchy body and stamping feet, a witches' caldron broke out. Her dance

\footnotetext{
7 The magazines emphasized that the Germans and Austrians could also see the sexual outcomes of uncontrolled 'black sexuality' even in front of their own doors - the dark-skinned children of the occupation solders. On the everyday racism according to them cf. Bauer 2002; Fehrenbach 2005; Satjukow \& Gries 2015.
} 
became wilder and wilder till Sonja gave up exhausted' (Neue Illustrierte 1962, No. 7, p. 12).
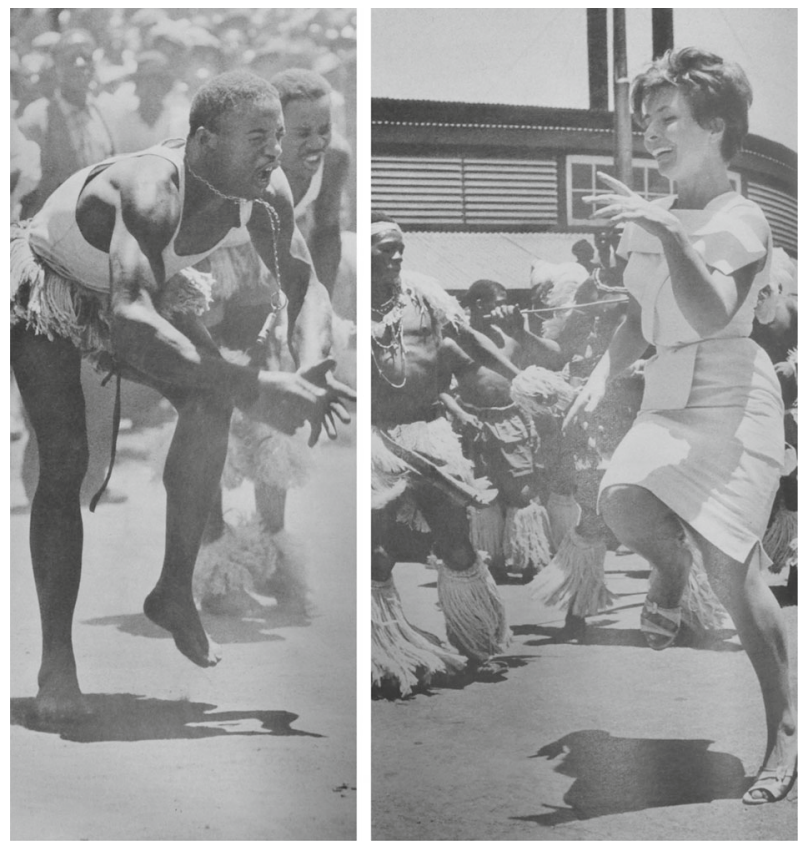

Neue Illustrierte 1962, No. 7, p.12

During the 1950s and 1960s, reports on the rampant sexual appetite of the blacks and in particular of black women became everyday topoi of the popular literature and of magazines and journals. The pictures and texts coined an anti-image of the Christian sex moral: The dark-skinned women would follow their sexual nature and abandon themselves to vice. In the 1960s and 1970s such women were attributed as 'racy' (rassig), what meant that they were hot-blooded, libidinous and lascivious. ${ }^{8}$ The discourse also forecasted future developments for (black and white) women, who were controlled by their drives: They will descend on a lower, more primitive or even animal level of civilization. With such a type of woman, the desired normality of the reconstruction family and the economic miracle society could not be achieved. On the contrary the Germans and Austrians needed real love relationships, stable marriages and (hetero-)sexuality based on Christian morals (Kral 2004).

In the German-speaking media of the 1950s and early 1960s, the image of the uncontrollable woman was also coined by the French actress Brigitte Bardot, e.g. in the film And God Created Woman (Et Dieu créa la femme; ... und immer lockt das Weib; 1956).

\footnotetext{
${ }^{8}$ For the etymology cf. Wortauskunftssystem zur deutschen Sprache in Geschichte und Gegenwarthttp://zwei.dwds.de/wb/rassig.
} 

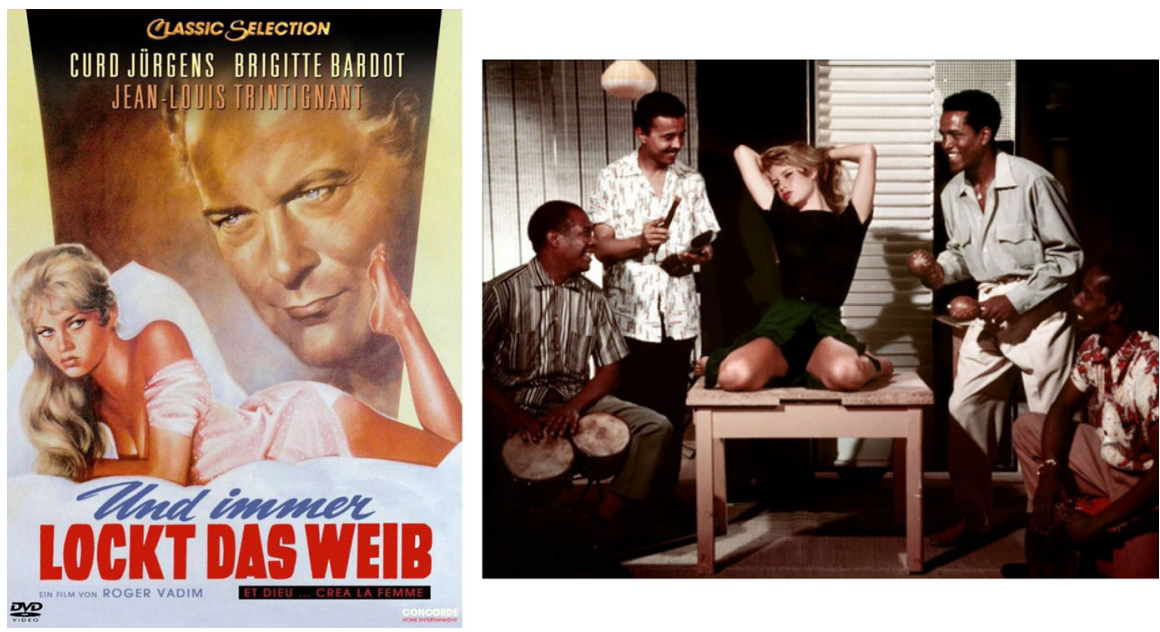

Poster and still from And God Created Woman, 1956

In this movie Bardot acted as a sexually excessive female called Juliette, as a 'good-bad girl' —as Dembicki and Feyerabend (1954) called her-driven by her vital energy. As the prototype of a 'modern French women', she became the darling of the German media. Juliette was adored for her love of life and her sex appeal, but she was also criticized for bringing troubles to all the males around her, who tried to seduce, to love and to marry her. This figure showed an essential difference between the American and French images: While the Hollywood starlet and the pinup girl finally ended in the harbour of marriage, the Juliette-type was not able for lifelong monogamy and prolonged her 'savoir vivre' within marriage. With the help of Bardot/Juliette, the journalist and commentators could perfectly discuss the gap between the Christian family values and the "new sexy woman'. The last was far away from the ideal of the four ' $\mathrm{Cs}$ ' - children, church, cooking, consumption-which the 'reconstruction society' and the 'economic miracle society' propagated for the housewife and mother. And she also did not fit to the clergy's requirements for premarital and extramarital abstinence.

Bardots image was so fascinating for the Austrian and German commercial media that she was often cloned by photographs and filmmakers. 


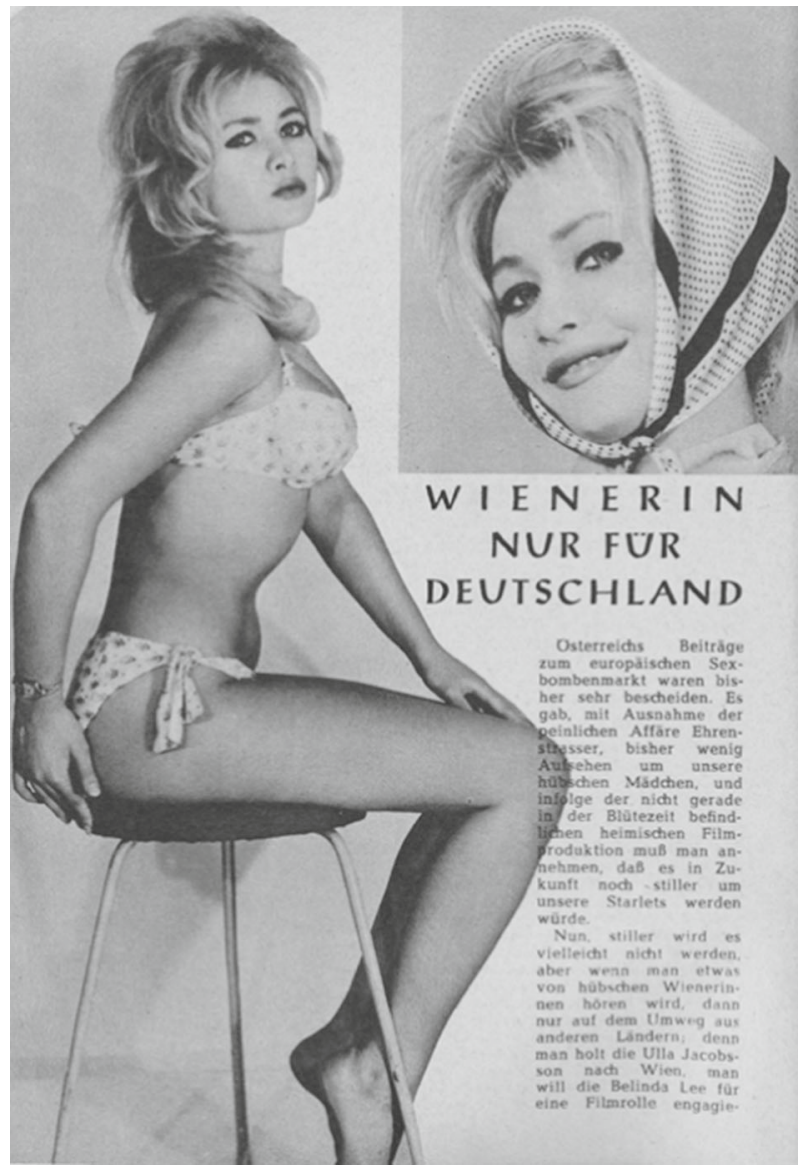

Wiener Magazin 1960, No. 4, p.16f

This picture showed Renate Rohm, who did not reach an international career, but only got an underpart in the German movie Girls for the Mambo-Bar (Mädchen für die Mambo-Bar; 1959). In the article she was recommended as Austrian contribution to the international 'market of the sex bombs', and may be, in some years 'one will not only speak about BB [Brigit Bardot] (...) but also about RR [Renate Rohm]' (Wiener Magazin 1960, No. 4, p. 16f.). 'Sexy beauties' like her were found at beauty contests and bikini shows, and advertising companies shaped them as idols and images in a variety of commercial campaigns (Eder 2007, p. $114 \mathrm{ff}$.).

Besides the Bardot vamp the journals also shaped another type of Frenchwoman: According to Praline (in 1954) this female was 'gracious, faithful and motherly (...) and at the same time very elegant. She will not come to the fore and will steer the thing with discretion: In the family, in company and in working life' (Praline 1954, No. 12, p. 12). One year later this woman was compared with a white American 
female: 'First of all, the Frenchwomen are women and they know that thereby they have the power over men. Even the American woman has the power, but she is feared therefore-the Frenchwoman is loved' (Praline 1955, April, p. 152). By her elegance, her charm and independence, this type of French woman was also distinct from the West German women which were represented in Praline in the figure of Maria Schell, an famous actress: Schell is seen as 'the ideal of the German picturebook woman with a lot of even temper, neatness and 'shot' of helplessness and camaraderie' (Praline 1955, April, p. 39). ${ }^{9}$

Manfred Delacour, who in 1958 wrote a whole book about the Parisian woman, concluded that the power of the Frenchwoman last but not least arose from her eye erotic which enabled her to 'gulp' and to bind a men. Using coquetry she 'is able to lickety-split register the weak sides of a man and then she does not let him go anymore' (Delacour 1958, p. 82). This ulterior conduct of a man is also used by her in family planning, because French women are educated in sexual matters by their mothers very early (Delacour 1958, p. 83). In the end the French benefit of the long tradition of their sexual culture and its outcomes, e.g. in the sleeping room: 'The big Parisian bed raises the frequency of intimate relations and contacts (...). Admittedly it is be said, that French men act according to the erotic needs of their spouses and mistresses and they are acting more subtle then the Northern Europeans and the people on the other side of the Rhine' (Delacour 1958, p.87).

In the middle of the 1960s, another type of French woman appeared in the German print media, which merged the Bardot figure with the silent leadership woman. Her archetype was Mirelle Darc, an actress, who according to Neue Illustrierte 'became the dream image of the French woman overnight'. Darc was not cagey about her intimate lifestyle, for instance 'about running barefoot, often up to the neck. She is lovely unprejudiced.' She used the terrace of her flat for 'naked sunbathing' and according to a TV interview she did not wear a nightdress or a pyjama during night, but 'nothing'. At the same time she was 'the most emancipated woman, which ever lived. In her wardrobe there are 22 trousers. No skirt. Also intellectually Mirrelle wears the breeches: She has signed a declaration of independence against men (...). Mirelle expressed this as follows: "When I take off my blouse at the street, it is exactly the same if a man pulls of his shirt. I do this, because I am hot. No to make the men crazy"' (Neue Illustrierte 1966, No. 30, p. 10f.). Before modern Frenchwomen like Mirelle Darc fell in love with a man who wants to bind them, they stayed independent and searched for temporal sex partners.

Images of independent Swedish women were also frequently used to speculate about the sex and gender roles of men and women in general and in Austria and West Germany in particular. In the early 1960s a Swedish movie provoked an enormous scandal and attracted millions to the cinemas: Ingmar Bergman's The Silence (Das Schweigen; 1963). The movie was irritating because it showed sexuality as a substitute and escape from social coldness and a family life lacking any true affection (Blaschitz 2014, p132ff.). Nevertheless 10.5 million German

\footnotetext{
9 When speaking about "German women", the authors always addressed women from the Federal Republic of Germany/FRG. Journals and magazines rarely wrote about women from the German Democratic Republic/GDR or other eastern European countries. Only a few articles dealt with the occupational life of females in the GDR.
} 
moviegoers watched it during the first 19 months-most of them because of its short sex scenes as episodes in a church and in a cinema as well as (the face of) a masturbating woman (Faulstich 2008, p. 292).

With references to the Swedish society, the long-term social consequences of the 'sex wave' and the liberalization of the penal law could be discussed. According to the contemporaries in the Swedish case, one could also observe the sexual consequences of the welfare state and the (mass) consumer society. Although the 'Swedish women' was a stereotype and the Swedish society of the early 1960s was still conservative regarding sex, in the German-speaking countries sexual liberty together with rational control and discipline were seen as rather quite unique Swedish characteristics (Marklund 2009, p. 83f.; Schröder 1996). In an article in the Neue Illustrierte (1965), the equivalent hopes and fears of the Germans were expressed: 'How free are Sweden's women? Words such as 'Swedes' or even 'Swedish women' make many Germans open their ears. For some these words are warning signals, for others they are a kind of exciting music. The average German thinks of nude bathing, immorality, being possessed by sex, alcohol abuse, the rule of women and the flight of men' (Neue Illustrierte 1965, No. 19, p. 12). For West German and Austrian males, who had just recently regained their dominance in marriage and family, the Swedish 'sex' culture promised not only pleasures, but also threats. ${ }^{10}$

The stereotype of the sexually liberal Swedish woman emerged in the 1950s with movies like Arne Mattssons Hon dansade en sommar (Sie tanzte nur einen Sommer; 1951) and Ingmar Bergmans Sommaren med Monika (Die Zeit mit Monika; 1952). Both films showed naked and sexually active young women (and men), who came in conflict with the rigid and conservative culture of the elder generation (in the first case) and had to deal with the problems of parenthood and marriage (in the second case). In particular, the bathing scene in Mattssons film was discussed by proponents of the left and right political parties and of church media. Most of them saw the Swedish sex culture as the realization of a world, in which the human nature and sexual desires collided with the legal and moral system (Beindorf 1996). In April 1955 the Time magazine published an article on 'Sin and Sweden', in which one could learn about the (supposed) liberal sex education of Swedish girls and their early sexual contacts with boys. ${ }^{11}$ Since then, Sweden became the 'dreamland' of European and American journalists writing about the sexual outcomes of the high living standard in the West.

Ten years later another Swedish movie stimulated the fears of the sexual outcomes of the liberal society. In 491 (1964) moviegoers could watch a homosexual rape scene as well as an intercourse between a girl and a dog. Because of these scenes, the film was first banned and then came out in a cut version for the European cinemas. In the German discourse the Swedish 'welfare state' with its allegedly rational and pragmatic sexual policies was regarded as responsible for

\footnotetext{
10 The story of the "Swedish Sin" was also told in other countries, e.g. in the Anglo-American world, cf. Lennerhed (1994), ch. 4 "Den svenka synden"; Hale (2003).

11 Most of this information did not come from surveys and statistics, but was based on conversations, e.g. with the famous sex educator Elise Ottesen-Jensen; cf. Hale (2003), p. 354ff.
} 
such extremes and as a prototype for the future development. Swedish sexual habits seemed to be a product of liberal politics and of a 'free' law system: In Sweden the abortion paragraphs were liberalized in 1938 (with medical, eugenic and social indications), in 1944 the anti-homosexual penal law was cancelled (and intercourse between adults became free) and since 1955 the schools were obligated to integrate sex education into the classes (Lennerhed 1994, p. 97; 2007). In 1971 Sweden also liberalized its pornography laws. From now on Sweden was hold responsible for the export of pornography books, prints and movies, especially to the German-speaking countries (where such products became legal in 1975). In fact, the sexual liberalism emerged in Sweden not until in the early 1960s and slowly superposed the rigid sexual mores and habits (Lennerhed 2014, p. 36).

Not surprisingly the Neue Illustrierte posed the following question in 1966: 'How do you want to see the Swedish woman?' and placed a photo with the comment: 'So or so?'

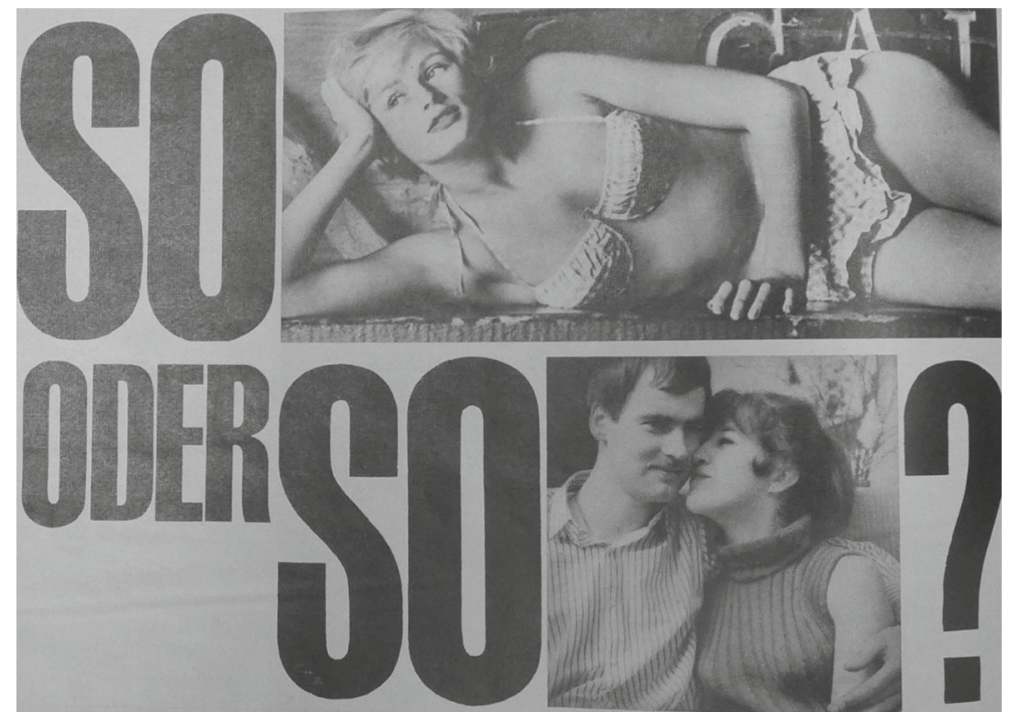

Neue Illustrierte 1966, No. 12, p.30

The answer was presented in the next issue under the title 'We love as we want' and listed the differences between Sweden and the FRG as well as Austria: 'Sex education in school with eleven. Free choice of partners even in the early youth. Equivalence for illegitimate children. Perfect equal rights. No objections against the anti baby-pill. Liberal laws on divorces. Legal termination of pregnancies' (Neue Illustrierte 1966, No. 13, p. 26). According to the author, in Sweden the practice of emancipation was not a 'empty word': 'Even the married wife keeps the master of her body. She is not submitted to the male demands and sexual longings. Quite recently a wife accused her husband for 'raping' her (...). As every man, the Swedish woman can search for her partner, she can be initiative and as a bachelor 
woman she can have so many lovers as she wants' (Neue Illustrierte 1966, No. 13, p. 29).

In 1967 Constanze reported about the consequences of 'Swedish style love'-one could be seen in the 'biological exhaustion' of the Swedish men: 'The explanation is simple: The Swedish woman is sexually "enlightened" and experienced. She claims her right to sexual happiness. And when such a little man (...) learns from his spouse, that she has expected something other from him, he can fail' (Constanze 1967, No. 17, p. 20). Here one of the fears was expressed, which most of the writers in the 1950s and 1960s rarely confessed: That their reports and images of sexually active and desiring 'other' females not only promised sexual pleasures, but raised demands that their lovers and husbands could not satisfy.

What were the tasks and aims of these textual and visual representations and images I have discussed in this article? First of all these images were used to transgress the borders of the 'own' and 'normal' gender and sexual culture of the German-speaking countries. By referring to images and narratives of the female 'other/s' and their sexual habits, the magazines, books and movies were able to show (half) naked female bodies and tell exciting stories about their sexual pleasures-or better about the sexual pleasures they promised to the male readers. There were three types of such women: (1) The Negro or black woman represented the atavistic, nature-determined female, who promised wild sexual adventures, but was placed on a lower step of civilization, which after the (sexual) chaos of war and the after war years still scared the people. (2) The sexy pinup girl, the Hollywood starlet and the Bardot figure stood for a type of woman who could conquer West Germany and Austria by means of the consumer culture and the American way of life. Although this type was widely distributed by the media, its future was not seen as a benefit: These females would bring 'cold' sex into the sleeping rooms, but also promiscuity, adultery and a downfall of feelings and love. Above all these females would not prove as stable marriage partners and good housewives and mothers. (3) The images of the 'normal' American woman, the Frenchwoman and the Swedish woman represented the type of the 'modern' emancipated woman. Because of her employment and own income, she captures an equal position in marriage, in the family and (for the most parts) even in public. As a result such women would also emancipate themselves in sexual matters. Sweden was seen as a model state, in which the social democratic employment policy, the liberalization of the laws and the realization of the welfare and consumer state have led to sexually independent and self-confident women. Although many male writers declared these Swedish women to be sex objects, they were fascinated by the fact that in social practice these women acted as self-conscious subjects.

Secondly, one should not forget that until the mid-1970s severe pornography laws endangered visual and textual transgressions, and therefore magazines, books and movies with sexual contents were threatened by censors and self-censorship (Blaschitz 2014). One strategy to avoid legal troubles was to report about foreign sexual mores and habits in a 'serious' and documentary way. Lots of articles, statistics and pictures were promoted as 'surveys', 'reports' and 'studies' with a scientific (ethnographical, sociological or psychological) background-and then it was also possible to illustrate them with erotic pictures and scenes. Another 
loophole was to mask them as sex education or as medical and psychological advice literature. Last but not least erotic images worked as a perfect motor for promoting consumer products as magazines, advice or report books and movies. In the 1950s and 1960s 'sex sells' became a still controversial but also progressive motto for advertising agencies and marketing specialists (Uhse 2002; Reichert 2003; Eitler 2009).

Thirdly, the discourse about the 'other' female and her sexuality not only dealt with foreign women and their images and stereotypes. In the end it focused on the German and Austrian counterparts and their recent and future sexual and gender roles, their place in society, marriage and the family. With the help of the 'other' woman, the authors could discuss about the possible developments of females and males in their own countries. What will happen with female sexuality, when Austria and Germany become consumer societies and welfare states, too? Will the emancipation of women also led to sexual 'freedom' for them and not only for men? What does it mean for men to live with such women and to be sensible lovers, loving fathers and cooperation partners in the households? (Moeller 1998, p. 106) Most of the writers-nearly all of them men-preferred an ambivalent view: On the one hand they feared disadvantages for their own patriarchal position. According to their opinion, the 'modern' sexualized woman was self-determined and egocentric, not so much interested in marriage and the family, she insisted in her own position in society, in the worst case also in her career, and wanted a male partner on an equal level. All this seemed to be a threatening scenario for the male authors and writers in Austria and Germany. On the other hand they were attracted and fascinated by the erotic and sexual advances these females announced. With these (foreign) women or better the images of them they could let their imagination run wild. In doing so-and implicitly writing about their own wishes and fears-they contributed to the spread of these images and to the implementation of such roles and scripting models during the 'little sex wave' of the 1950s and 1960s.

Acknowledgments Open access funding provided by University of Vienna.

Open Access This article is distributed under the terms of the Creative Commons Attribution 4.0 International License (http://creativecommons.org/licenses/by/4.0/), which permits unrestricted use, distribution, and reproduction in any medium, provided you give appropriate credit to the original author(s) and the source, provide a link to the Creative Commons license, and indicate if changes were made.

\section{References}

Bänziger, P.-P., \& Stegmann, J. (2010). Politisierungen und Normalisierung: Sexualitätsgeschichte des 20. Jahrhunderts im deutschsprachigen Raum. http://hsozkult.geschichte.hu-berlin.de/forum/201011-001. Accessed 25 Mar 2015.

Bänziger, P.-P., et al. (Eds.). (2015). Sexuelle Revolution? Zur Geschichte der Sexualität im deutschsprachigen Raum seit den 1960er Jahren. Bielefeld: Transcript.

Bauer, I. (2002). Die Amis, die Ausländer und wir: Zur Erfahrung und Produktion von Eigenem und Fremdem im Jahrzehnt nach dem Zweiten Weltkrieg. In I. Bauer, J. Ehmer, \& S. Hahn (Eds.), Walz- 
Migration-Besatzung. Historische Szenarien des Eigenen und des Fremden (pp. 197-276). Klagenfurt: Drava Verlag.

Beindorf, C. (1996). Sie tanzte nur einen Sommer. Konstruktion und Rezeption von Stereotypen (Vol. 4). Humboldt-Universität zu Berlin: Arbeitspapiere "Gemeinschaften".

Blaschitz, E. (2014). Der "Kampf gegen Schmutz und Schund”. Film, Gesellschaft und die Konstruktion nationaler Identitä in Österreich. Wien \& Berlin: LIT Verlag.

Brauerhoch, A. (2006). Fräuleins und Gis. Stroemfeld: Geschichte und Filmgeschichte. Frankfurt a. M.

Cook, H. (2004). The long sexual revolution: Women, sex, and contraception in England 1800-1975. Oxford: Oford University Press.

Dabhoiwala, F. (2012). The origins of sex: A history of the first sexual revolution. New York: Oxford University Press.

Dembicki, L., \& Feyerabend, W. (1954). Die Sexualität der Frau: Eine Auseinandersetzung mit Kinsey. Stuttgart: Verlag für Sexualliteratur.

Eder, F. X. (2006). Historische Diskurse und ihre Analyse-eine Einleitung. In F. X. Eder (Ed.), Historische Diskursanalysen. Genealogie, Theorie, Anwendungen (pp. 9-23). Wiesbaden: VS Verlag für Sozialwissenschaften.

Eder, F. X. (2007). The nationalists' 'Healthy Sexuality' was followed by America's influence: Sexuality and media from national socialism to the sexual revolution. In G. Bischof, A. Pelinka, \& D. Herzog (Eds.), Sexuality in Austria (=Contemporary Austrian Studies 15) (pp. 102-130). New Brunswick: Transaction Publishers.

Eder, F. X. (2009). Kultur der Begierde: Eine Geschichte der Sexualität. München (2nd ed.). Frankfurt: C.H. Beck.

Eder, F. X. (2014). The long history of the 'Sexual revolution' in West Germany. In G. Hekma \& A. Giami (Eds.), Sexual revolutions (pp. 99-120). New York: Palgrave Macmillan.

Eder, F. X. (2015). Die lange Geschichte der 'Sexuellen Revolution' in Westdeutschland (1950er bis 1980er Jahre). In P.-P. Bänziger, et al. (Eds.), Sexuelle Revolution? Zur Geschichte der Sexualität im deutschsprachigen Raum seit den 1960er Jahren (pp. 25-61). Bielefeld: Transcript.

Eder, F. X., \& Kühschelm, O. (2014). Bilder-Geschichtswissenschaft-Diskurse. In F. X. Eder, O. Kühschelm, \& C. Linsboth (Eds.), Bilder in historischen Diskursen (pp. 3-44). Wiesbaden: VS Springer.

Eitler, P. (2009). Sexualität als Ware und Wahrheit: Körpergeschichte als Konsumgeschichte. In H.-GHaupt \& C. Torp (Eds.), Die Konsumgesellschaft in Deutschland 1890-1990: Ein Handbuch (pp. 370-388). Frankfurt am Main \& New York: Campus.

Faulstich, W. (2008). Das Schweigen: Ein Film schockiert Deutschland. In G. Paul (Ed.), Das Jahrhundert der Bilder: 1949 bis heute (pp. 290-297). Göttingen: Vandenhoeck \& Ruprecht.

Fehrenbach, H. (2005). Race after Hitler: Black occupation children in postwar Germany and America. Oxford: Princeton University Press.

Fichna, W. (2004). Rock 'n' Roll und Beat in Wien: Populäre Musikstile zwischen Untergrund und Oberfläche. In Roman Horak, et al. (Eds.), Randzone: Zur Theorie und Archäologie von Massenkultur in Wien 1950-1970 (pp. 163-180). Vienna: Turia und Kant.

Friedeburg, L. V. (1953). Die Umfrage in der Intimsphäre. Stuttgart: Enke.

Gernig, K. (2001). Zwischen Sympathie und Idiosynkrasie: Zur Wahrnehmung des anderen Körpers zwischen Sympathie und Idiosynkrasie in kulturanthropolgischer Perspektive. In K. Gernig (Ed.), Fremde Körper. Zur Konstruktion des Anderen in europäischen Diskursen (pp. 13-29). Berlin: Dahlem University Press.

Hale, F. (2003). Time for sex in Sweden: Enhancing the myth of the "Swedish Sin" during the 1950s. Scandinavian Studies, 75(3), 351-374.

Heineman, E. D. (2006). The economic miracle in the bedroom: Big business and sexual consumption in reconstruction West Germany. Journal of Modern History, 78(4), 846-877.

Heineman, E. D. (2011a). Before porn was legal: The erotica empire of Beate Uhse. Chicago: University of Chicago Press.

Heineman, E. D. (2011b). Sexuality in West Germany: Post-Fascist, Post-War, Post-Weimar, or PostWilhelmine? In F. Kießling \& B. Rieger (Eds.), Mit dem Wandel leben: Neuorientierung und Tradition in der Bundesrepublik der 50er und 60er Jahre (pp. 229-245). Köln: Böhlau.

Hekma, G., \& Giami, A. (2014). Sexual revolutions: An introduction. In G. Hekma \& A. Giami (Eds.), Sexual Revolutions. Basingstoke et al: Palgrave Macmillan.

Herzog, D. (2005). Die Politisierung der Lust: Sexualität in der deutschen Geschichte des 20. Siedler: Jahrhunderts. München. 
Herzog, D. (2006). The reception of the Kinsey Reports in Europe. Sexuality and Culture, 10(1), 39-48. Hoffmann, S. (2000). Darüber spricht man nicht? Die öffentliche Diskussion über die Sexualmoral in den 50er Jahren im Spiegel der Frauenzeitschrift 'Constanze'. In J. Meyer-Lenz (Ed.), Die Ordnung des Paares ist unbehaglich: Irritationen am und im Geschlechterdiskurs nach 1945 (pp. 57-83). Hamburg: Lit.

Jordan-Zachery, J. S. (2009). Black women, cultural images and social policy. New York et al.: Routledge.

Koch, L., \& Tallafuss, P. (Eds.). (2007). Modernisierung als Amerikanisierung? Entwicklungslinien der westdeutschen Kultur 1945-1960. Bielefeld: Transcript.

Kral, S. (2004). Brennpunkt Familie. 1945 bis 1965. Sexualität, Abtreibungen und Vergewaltigungen zwischen Intimität und Öffentlichkeit. Marburg: Jonas Verlag.

Lennerhed, L. (1994). Friheten att njuta: Sexualdebatten i Sverige på 1960-talet. Stockholm: Norstedts.

Lennerhed, L. (2007). Taking the middle way: Sex education debates in Sweden in the early twentieth century. In L. Sauerteig \& R. Davidson (Eds.), Shaping sexual knowledge: A cultural history of sex education in twentieth-century Europe (pp. 55-70). New York: Routledge.

Lennerhed, L. (2014). Sexual Liberalism in Sweden. In G. Hekma \& A. Giami (Eds.), Sexual Revolutions (pp. 25-45). Basingstoke et al.: Palgrave Macmillan.

Manghani, S. (2013). Image studies: Theory and practice. London et al.: Routledge.

Mar Castro Varela, M., \& Dhawa, N. (2005). Postkoloniale Theorie: Eine kritische Einführung. Bielefeld: Transcript.

Marklund, C. (2009). Hot love and cold people. Sexual liberalism as political escapism in radical Sweden. Nordeuropaforum. Zeitschrift für Politik, Wirtschaft und Kultur 19(1), 83-101.

Marklund, C. \& N. Glover (2009). Arabian nights in the midnight sun? Exploring the temporal structure of sexual geographies. Historisk Tijdskrift 129(3)

Mayer, J. (2014). Das Eigene und das Fremde: Eine Analyse von Frauenbildern in den Zeitschriften Wochenend und Praline, 1950er und 1960er Jahre. Wien: Diplomarbeit Univ.

Menzel, E. \& Krafft, G. (1961). Die beiden Geschlechter. Liebe und Ehe im menschlichen Leben. Salzburg: Andreas Verlag.

Moeller, R. G. (1998). The "Remasculinization" of Germany in the 1950s: Introduction. Signs, 24(1), 101-106.

Muthesius, A. (1959). Die Afrikanerin. Düsseldorf: Hellas-Verlag.

Poiger, U. G. (1996). Rock 'n' Roll, female sexuality, and the cold war battle over German identities. Journal of Modern History, 68(3), 577-616.

Reichert, T. (2003). The erotic history of advertising. Amherst: Prometheus Books.

Reisigl, M., \& Wodak, R. (2001). Discourse and Discrimination. Rhetorics of racism and antisemitism. London et al.: Routledge.

Reuter, J. (2002). Ordnungen des Anderen. Zum Problem des Eigenen in der Soziologie des Fremden. Bielefeld: Transcript.

Said, E. (1985). Orientalism. Harmondsworth: Penguin Books.

Satjukow, S., \& Gries, R. (2015). Bankerte! Besatzungskinder in Deutschland nach 1945. Frankfurt a. M. \& New York: Campus Verlag.

Schissler, H. (2001). "Normalization" as project. Some thought on gender relations in West Germany during the 1950s. In H. Schissler (Ed.), The miracle years: A cultural history of West Germany (pp. 359-375). Princeton: Princeton University Press.

Schröder, S. M. (1996). Mehr Spaß mit Schwedinnen? Funktionen eines deutschen Heterostereotyps (Vol. 3). Humboldt-Universität zu Berlin: Arbeitspapiere "Gemeinschaften".

Sieburg, F. (1951). Vom Unfug der Entblößung. Constanze, 10, 7.

Steinbacher, S. (2011). Wie der Sex nach Deutschland kam: Der Kampf um Sittlichkeit und Anstand in der frühen Bundesrepublik. München: Siedler.

Thissen, R. (1995). Sex verklärt: Der deutsche Aufklärungsfilm. München: Heyne.

Uhse, B. (2002). Sex Sells. Die Erfolgsstory von Europas größtem Erotik-Konzern. München: Knaur.

Varisco, D. M. (2007). Reading orientalism: Said and the unsaid. Seattle et al.: Univ. of Washington Press.

Vogel, A. (1998). Die populäre Presse in Deutschland. Ihre Grundlagen, Strukturen und Strategien. München: Fischer.

Wagnleitner, R. (1994). Coca-colonization and the cold war: The cultural mission of the United States in Austria after the second world war. Chapel Hill: University of North Carolina Press. 